\title{
Improvement of Reading Skills in the Second Foreign Language Courses by the "Anti-Method" Way
}

\author{
Bünyamin Celik ${ }^{1}$ \\ ${ }^{1}$ Department of Languages, Ishik University, Erbil, Iraq \\ Correspondence: Bünyamin Celik, Department of Languages, Ishik University, Erbil, Iraq. E-mail: \\ bunyamin.celik@ishik.edu.iq
}

Received: January 11, 2018 Accepted: February 8, 2018 Online Published: April 24, 2018

doi:10.5539/ijel.v8n4p237

URL: https://doi.org/10.5539/ijel.v8n4p237

\begin{abstract}
The four basic skills in the foreign language education can only be achieved with the good reading skills and habits. Due to the fact that reading skills is usually perceived as a self-sustaining skill, the improvement of reading skill is carried out by the traditional reading activities. Traditional reading activities are carried out with the teacher-centered understanding. Nowadays, reading in the foreign language would have a different precaution because of the increasing need of foreign language in different professions. In this study, in order to bring innovation to the teacher-centered reading activities, the "Anti-Method" alternative way is introduced in detail to the students who are learning a foreign language. This method is used in the Education Faculty of Iraq Ishik University in an elective course for third grade students who participate in the Turkish Language. After application, this method is evaluated on the basis of feedbacks from students.
\end{abstract}

Keywords: reading, reading skills, foreign language, anti-method, improvement of foreign language teaching

\section{Introduction}

Every second in our growing and developing world, the need of learning a foreign language is increasing. Reading skills is the most important skill in the four skills of the foreign language techniques and practices. "Reading is an important gateway to personal development, and to social, economic and civic life" (Holden, 2004). The use of text in the foreign language education is meant to present a "cultural" linguistic activity to the students (Buttaroni, 1997, p. 227). In addition, new vocabularies, idioms and cultural expressions in the reading activities provide fluency in speaking foreign language (Rowe \& Goldin-Meadow, 2009). In addition, gestures, dialects, intonations, semiotics, and norms specific to children's cultural experiences, especially English language learners, can positively affect student learning (Diaz-Rico, 2013, p. 172). "The three stages of the reading process are into, though, and beyond, or pre-reading, during-reading, and post-reading".

The teacher makes preparations about the text such as brain storming, question-answer technique and picture description related to the main topic of the text. During reading, different interpretations and understandings are expected from students after this stage, students should understand what they read and analyze them. This process is usually done by asking questions to the students about the text (Ehlers, 1996). Furthermore, the current method of trying to improve students' comprehension is for teachers to ask questions and have students answer them (Durkin, 1979, 1984; Singer, 1978).

However, if instructors always lecture traditionally, they will not avoid monotony and activate the students who get bored. If lectures are monotonous, students will be exposed to ineffectual and nonproductive courses.

The purpose of this study is to bring new approaches or a new dimension to the reading course which is shaped by these three traditional stages by the way of "Anti-Method".

\section{Anti-Method Way}

In the academic sense, the "Anti-Method" way is developed by the Susanna Buttarani and Alfred Knapp in Vienna, in the 80 's for adults and young foreign language students, and this method especially emphasize on the reading skills outside traditional methods (Buttaroni / Knapp, 1988). "Anti-Method" way is based on Noam Chomsky's "Universal Grammar" theory. "Language is simply grafted on top of cognition as a way of sticking communicable labels onto thoughts" (Fodor, 1975; Piaget, 1926) and according to the "universal grammar" theory, language and linguistic abilities are classified in the brain by means of parameters with an innate ability 
of human beings (Lewandowski, 1994, p. 1206). However, the method will not be explained in detail in this study, the applications of this method will be discussed.

This method is established for understanding and reading skills. However, the contributions of this method are quite high on the vocabulary teaching, writing and speaking skills.

As Eli Hinkel points it out, "in meaningful communication, people employ incremental language skills not in isolation, but in tandem" (Hinkel, 2006, p. 113) and also "despite our history of treating the four skills in separate segments of a curriculum, there is a recent trend toward skill integration".

"Anti-Method" is constituted 3 main stages and these lower stages. However, there is no prepared lesson plan for this method. At this point, the important thing is that whether the lesson plans can be applied equally in each class or not.

"Language without culture is unthinkable, so is human culture without language" (Wei, 2005). "Mastering in a language requires learners' mastery of the cultural contexts in which the language occurs" (National Standards in Foreign Language Education Project, 1996, p. 27 in Peterson and Coltrane, 2003). Moreover, "they have to understand that, in order for communication to be successful, language use must be associated with other culturally appropriate behaviors" (Peterson \& Coltrane, 2003).

Foreign language learners who have a lot of different positions and situations especially cultural and environmental influences, have both chance to apply appropriate lesson plans to their own conditions and make the method more useful and productive on the cultural dimension of target language. Therefore, the teachers can make changes on the applied methods and shape the method according to the student group. For this reason, a sample lesson plan was prepared considering the levels of students and the content of lessons, and the method is introduced by visualizing.

"Anti-Method" includes three different main stages: Listening, Reading and Crosswords. Each stage has its own sub-stages and different application methods. In this part, the stages of "Anti-Method" will be introduced in detail.

\subsection{Stage 1 Listening}

"Listening is a process of understanding of verbal data and interpretation. Listening is an action in which many processes are realized interactively and based on understanding" (Keçik \& Uzun, 2004, p. 111). The first stage of method includes three sub-stages. These stages are shaped due to listening. Listening activities are the most important activity in foreign language education and the teacher has an important role. According to Anderson, the "Watch out!" and "Listen carefully!" are totally useless warning to the students (Anderson, 1960, p. 93).

\subsubsection{Sub-stage 1: Listening and Verbal Information Exchange}

The text is listened firstly to the students with tape player/CD or smart board. If there is no Professional sounding of text, the teacher can also read the text for students. However, the teacher should not read the text quickly and should pay attention to the emphasis of words except from pronunciation. Before reading text, the teacher should encourage and motivate the students to listening.

After first listening, students share what they understand from the text with each other. In this process, the students should benefit from the positive effects of expressing themselves by using their native tongue.

Atkinson (1987, p. 242) agrees with Bolitho (1983) that permitting students to use their L1 brings a "valuable "humanistic" element" into the language classroom, allowing students to express themselves clearly and effectively.

In the learning foreign language, especially second foreign language process, the teacher should encourage the students to participate in-class activities and verbal sharing with the humanistic approaches. "The speech of students should not be cut off or the completion of the missing or the correction of wrong should be left to the end" (Gürgen, 2008, p. 56). "The presentation of any subject, the discussion, the reading of text, singing a song etc. provides that the students learn more different words and contribute to their vocabulary" (Temur, 2006).

\subsubsection{Sub-stage 2: Listening and Written Information Exchange}

In sub-stage 2, the difficulty level of text should be considered and listened several times. In the last listening, it is asked to take note of the three to five words which are not familiar for students. Then, students are divided into the dual, triplet or quartet groups and they discuss spelling of words or what they mean in their mother tongue. Students should not use dictionary in this stage and also they cannot translate sentences one-to-one to their mother tongue. Also "translation should be avoided, although the native language could be used in order to 
explain new words or to check comprehension" (Richards \& Rodgers 2001, p. 10).

\subsubsection{Sub-stage 3: "Living Dictionary": Information Exchange in-Class}

The last sub-stage is called "living dictionary". In this sub-stage, words which are not understood are directed to the whole class. If the words cannot be answered, the teacher gives the meaning of the word. Words should be noted carefully by the students.

After this process, the text is played twice or three times again. Then, this time different groups are created and the information obtained are shared within the group. The purpose of repeating this process provides that the different information is shared and students can socialize each other. Finocchiaro \& Brimful (1983, p. 219 ) define group work as "work in which the class broken into small groups of form three to eight students they work simultaneously on the some task or be given different tastes of varied types or levels". Naturally, group works with different activities provide enjoyable benefits for both learners and teachers.

Al-Hamash (1985, p. 88) states it as "more than one group of students can be engaged in language use simultaneously. The teacher just assists in facilitating the work and in solving some of the problems that might arise in the course of action".

Too much playing/reading the text can cause the students to feel bored and they may not pay enough attention to the lessons, for this reason students may be asked questions about the content of text, or different exercises can be done such as textual matching, correct-wrong or picture description. Finally, the text should be listened / read one more time. This activity should be limited (to) 40 minutes.

\subsection{Stage 2 Reading}

The second main stage of (the) method is shaped by the three different skills and 3 sub-stages. The text is being read, understood and discussed.

\subsubsection{Sub-stage 1: Individual Reading}

As it is known, the materials used in the classroom for learning and acting foreign language should be modern and interesting. At the same time, selected reading texts in the reading skills are more permanent and faster when considering age, cultural differences and environmental factors of learners. "Reading texts should be based on reality and should have rich content and measured length form. In addition, teachers should excite attention of students" (Ortner, 1998, p. 109).

At this stage, the text which written in foreign language is shared with students and they read this text alone and silently. Then, the students are asked to discuss the subject of text with their friend or small groups.

\subsubsection{Sub-stage 2: Individual Reading, Underlining Interesting Words}

During the second carefully-reading stage, the students are asked to underline three-four new words or words that they do not know what they mean. In dual groups, the meanings of these words are tried to be explained, in other words, to be solved. Unintelligible words are presented again to the whole class. If there is no answer from students, the teacher helps the students to understand this word. These unknown words should be carefully noted by the students.

\subsubsection{Sub-stage 3: Common Dictionary, Individual Reading}

As each student notes the word which is useful for their own vocabulary level, they form "Common Dictionary" after the activity mentioned above. Then the students read the text again, underline the words and exchange information among the groups. Thus, the new words are added to the students' dictionary.

\subsection{Stage 3 "Lingua-Puzzle", Writing}

This stage is called "Lingua-Puzzle" which includes only one stage writing-understanding activity. In-class games and puzzle activities influence learning process positively and offer the opportunity to practice what is known" (Demirel, 1978).

Approximately 30 or 40 seconds of the text is listened to the students and the students are asked to write as much as they can while listening. The same part is played or read twice and then it is asked to the students to complete the missing part. Then, students compare what they write with their friends and correct the wrong places. "The puzzle method provides repetition of the words that students learn and teach new words to them" (Karatay, 2007).

After this process, the text is played again and the students try to complete missing writings. Then, different dual groups complete the missing places and correct the wrong of writings. In this way, "Puzzle" should be 
completed.

The text is played again and individual writing process starts again, however this time the missing places or mistakes are corrected and completed by trio or group of four. The same process should be repeated until the text is completed. It depends on the preference or purpose of the teacher.

After $85 \%$ or $95 \%$ part of text is written by groups, the text is presented to the teacher. In the meantime, all alternatives presented to the teacher are noted. Unintelligible places are played again in tape-record and the text is finalized. Then, the correct form of the text is written on the notebooks of students. Throughout this process, students will learn how (to) examine and understand the text step by step. In addition, "it is seen that this kind of puzzle exercises improve students' ability to understand what they read" (Gümüş, 2010).

It is clear that the most important point in the foreign language education is taking necessary notes and correct notes in all listening, reading and writing activities. According to Di Vesta and Gray, "increasing the attention to the lecture and inducing the students to compare the information heard with prior knowledge" (DiVesta \& Gray, 1972) and "Taking note is one of the first and most established cognitive technology" (Dror, 2007). As such, it offloads cognitive processes and extends our "in head" cognitive abilities (Dror \& Harnad, 2008). Thus, taking note ensures that new words are easier to memorize with reading and listening skills.

Language learning is a process. The student should adopt a self-guided strategy in order to be effective in learning foreign language. The "Anti-Method" is helpful to develop students' own strategy and how they learn and study individually.

\subsection{A Sample Course Schedules Directed to Anti-Method}

The course schedule of this method is composed of two lessons which continue for 50 minutes, a total of 100 minutes program. The time, the function and the application of the method, the activities in the class and the equipment to be used are taken into account in the formation of the curriculum. The method is summarized by summarizing in the following table consisting of five points, and the processing of the method presented in detail before this is visualized.

It does not matter at which level the chart is applied. The same chart can be applied at each level. The variable is the text selection according to the level of the student.

\subsubsection{Anti-Method" Sample Lesson Plan}

Table 1. Lesson plan for Grade 3 ELT department

\begin{tabular}{|c|c|c|}
\hline Group: & Grade 3 ELT Department / Group & \\
\hline Date: & $7 / 12 / 2007$ & \\
\hline Lesson: & 1 and 2 & \\
\hline Duration: & $50+50$ Totally 100 Minutes & \\
\hline Topic: & "Gençler İşsizlikten, Patronlar İşçisizlikten" & \\
\hline \multicolumn{3}{|c|}{ Objectives } \\
\hline \multicolumn{3}{|c|}{ 1. By the end of the lesson learners will be able to speak about jobs and about what the good jobs are. } \\
\hline \multicolumn{3}{|c|}{ 2. Learners will be introduced to 'nouns'; iş, 'kalifiye', ... } \\
\hline \multicolumn{3}{|c|}{ 3. Learners will review verbs 'denemek', 'yarmak'... } \\
\hline \multicolumn{3}{|c|}{ Materials } \\
\hline \multicolumn{3}{|c|}{ 1. Some news bulletin/report about jobs } \\
\hline \multicolumn{3}{|c|}{ 2. Course book and Flashcards about the text } \\
\hline \multicolumn{3}{|l|}{ 3. Tape-recorder } \\
\hline \multicolumn{3}{|c|}{ Lesson 1} \\
\hline \multicolumn{3}{|c|}{ Duration: 50 Minutes } \\
\hline PROCEDURES & EXPLANATION & \\
\hline PHASE 1 & & Time \\
\hline 1- Function & Entrance / Salutation & \\
\hline 2- Application & Introducing Anti-Method & 5 \\
\hline 3- Activity & Presentation of Teacher & Mins. \\
\hline 4- Goal & Give Prior Knowledge & \\
\hline PHASE 2 & Stage 1 Listening & Time \\
\hline 1- Function & Sub-stage 1: Listening and Verbal Information Exchange & \\
\hline 2- Application & Listening/Reading of the text \& Sharing of what students understand & 10 \\
\hline 3- Activity & Teacher Presentation \& Dual Studying & Mins. \\
\hline 4- Goal & İmprovement of listening skills $\&$ Provide communication, so improve understanding & \\
\hline
\end{tabular}




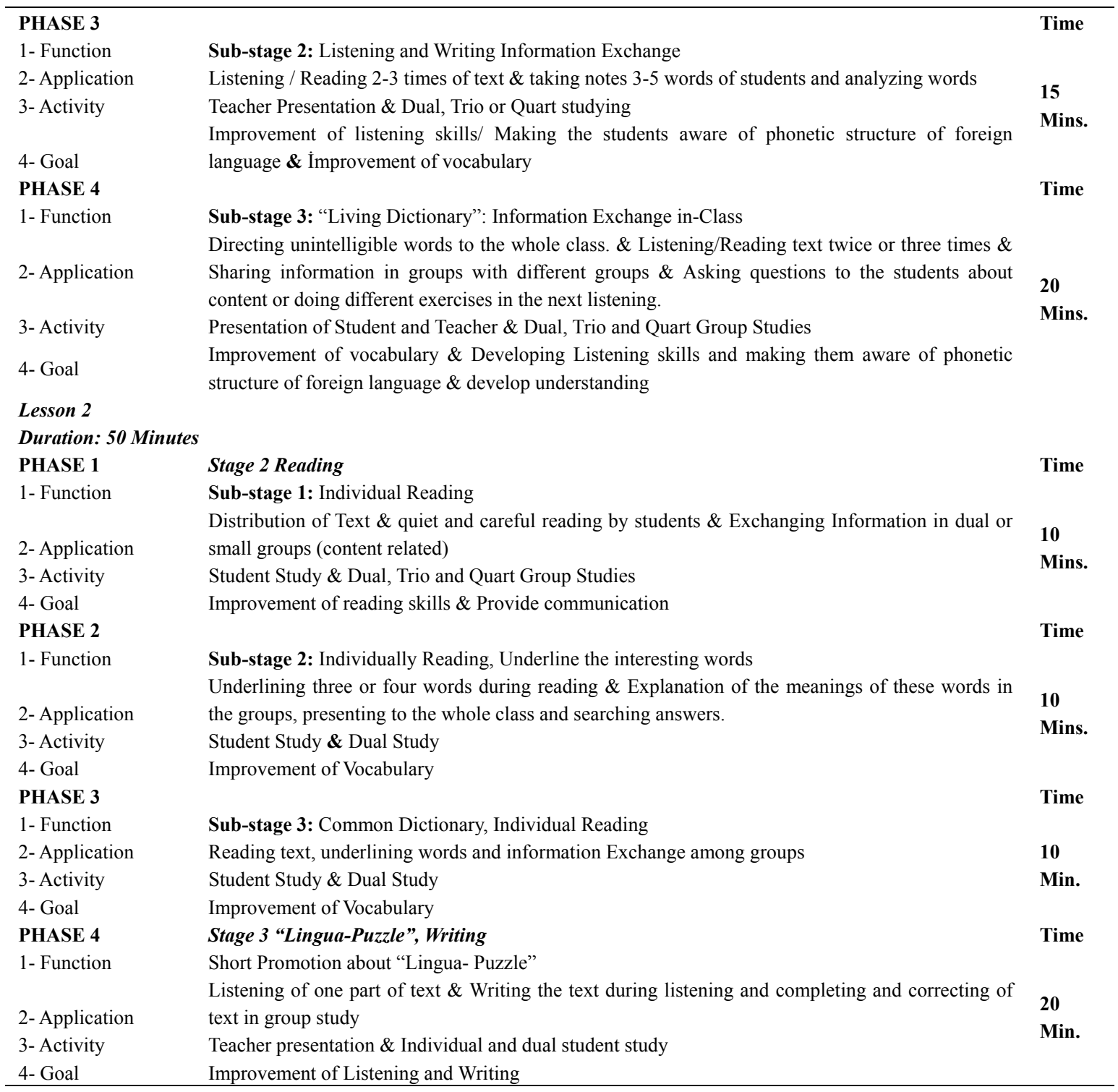

\section{The Application of "Anti-Method"}

The "Anti-Method" way is applied on the third grade students who pass on the 3A class in the English Language Teaching, in the Faculty of Education of Ishik University with the text of "Gençler İşsizlikten, Patronlar İşçisizlikten" (Tömer, 2008; Yeni Hitit 2, p. 7) (See Appendix D) within the 50+50 minutes 2 courses. At the same time, the other class $3 \mathrm{~B}$ grade students are entered the same reading part with the same timing, 50+50 minutes, 2 courses. After one week, two classes are tested with questions about the text and their results are compared each other. Hitit Turkish Teaching Set which is prepared by the Ankara University TÖMER Turkish and Foreign Language Research and Application Center is presented in many places of the world to the Turkish teachers, institutions and organizations. This set which is prepared for a person who wants to learn Turkish in Turkey or abroad includes four basic teaching materials (reading, writing, listening, and speaking). For this reason, this book has been chosen as reliable reference source. The students can select the Turkish course from the first semester.

Two separate measurements and evaluations were made to achieve correct and definitive result. First measurement and evaluation is made with the same exam by comparing numerical results and percentage of the class which is applied Anti-Method and the other equivalent class that has not been applied this method. As a second evaluation, a questionnaire study was conducted to evaluate motivations of educators, the pedagogical approach of them and the relevance (of the) method.

A mini preliminary questionnaire is applied to get the opinions of both control and experimental group students 
who selected the Turkish course as a second foreign language (See Appendix A). Thus, this questionnaire provides information about the opinions of students whose second foreign language is Turkish. In addition, this questionnaire will also play an important role in the assessment and understanding of results.

Experimental Group Grade 3A students who participate in the research and applied Anti-Method consisted of 24 students whose age average is $22-24,16$ of whom are girl and 8 of whom are boy. $20 \%$ of class are lectured Turkish class in high school. No one has been in Turkey before. The whole class answered as "yes" to the question whether they know Turkish or not. They stated that they know Turkish a little and the Turkish lessons (grammar, simple sentences, numbers and words) are not useful. $85 \%$ of students stated that Turkish is a difficult language, $80 \%$ of them had difficulties in Turkish sense and $95 \%$ of them were not interested in this course. However, considering the regional conditions, $68 \%$ of students think that the Turkish is necessary for their future and know that Turkish language increase their opportunity to find a job.

10th question of questionnaire is open to the interpretation, "How should a foreign language lesson be for you?" Many of the students answered as the following:

$>$ More reading and listening sources should be about Turkish language.

$>$ Turkish lessons should be student-centered and follow correct strategies, not only word-based grammar rules.

$>$ The teacher should have both pronunciation and grammar.

$>$ It is possible only with teachers who like Turkish language and adopt modern teaching techniques to language learning.

$>$ It should be enjoyable as much as possible and then Turkish language course will be preferred. Not only should the teacher focus on grammar.

$>$ The necessity of second foreign language and importance of learning new language should be better explained to the students and they should be encouraged.

$>$ It should not be an abstract course. The learners should be aware that Turkish is not only grammar.

$>$ They think it is important to create the environment in which they use this language. If there were this environment, students would like this lesson and learning would become permanent.

$>$ Increase the number of activities to develop 4 basic skills (speaking, writing, reading, and listening).

$>$ All new materials should be used and developments should be followed by both students and teachers.

$>$ Different speaking tactics should be given.

$>$ It should be a student-centered course, and use new methods.

$>$ The difficulties of Turkish language should be processed with games, music or interesting teaching strategies.

As seen in these explanations, students get bored of traditional lesson methods, they emphasize that foreign language lessons should be more effective with games, music and contemporary methods. The necessity and importance of grammar in language is undoubtedly a major point. However, with Turkish which has a complex grammar structure, the students get easily bored. As a result, students demand a student-centered education both with new language and different activities.

Teachers who have pedagogical, psychological and philosophical education are aware that lecturing foreign language is not only about grammar knowledge, but also there are contemporary methods. Therefore, it is observed that students more active in the lessons with the new, interesting and contemporary way of "Anti-Method".

\section{The Application of Improvement Method of Foreign Language}

After questionnaire, the text, "Gençler İşsizlikten, Patronlar İşçisizlikten" (Tömer, 2008; Yeni Hitit 2, p. 8) is selected to apply on students. It is noted that the text is suitable with Turkish lesson which is the second foreign language. In the Yeni Hitit Textbooks, units are determined according to the level; texts are given in a balanced way with activities such as listening, reading, dual conversation, verbal narrative and written expression skill levels, and each of these activities is given with titles available to understand easily.

The text is fictionalized both attractively and simply. The purpose of this method, not to put students out of the way by applying difficult text, but to provide students easily solve and independent work of them. 
"In education, especially language education, the texts are very important because the language education is carried out in the center of texts" (Çeçen \& Çiftçi, 2007, pp. 39-49). In a Turkish course, the textbook is the most important source after the teacher (Küçük, 1996). For this reason, the quality of textbook and how teacher used these in education process are extremely important to reach the targeted achievements (Duman, 2003, pp. 151-155).

As can be clearly understood from the discussions, teachers have important role at this point. They should know the level of the students and choose the content of the course accordingly. In addition, it is important to select attractive content to prevent students from getting bored. The end of selected text should arouse curiosity among students.

In the main sub-stage of Stage-1 Listening, "Listening and Verbal Information Exchange" text is read twice and it is expected that they listen carefully. After reading, students share with their colleagues what they understand from the content of the text. This process is realized in students' mother tongue. However, as mentioned before, the teacher can appropriately shape teaching methods; play with methods and make them suitable to the lesson. At this point, the teacher can read the text one more and ask students to tell the story of text on foreign language by visiting the student groups. S/he also encourages them to speak foreign language.

In the second sub-stage of Listening which is "Listening and Written Information", the text is read again and students underline 3-5 words that they did not know what they mean. Then, they form four-man team and share their writings with each other, briefly they exchange the information and they try to learn meaning of words. They compare and discuss these words in their own groups. The most important point here is that using dictionary is forbidden. Later, the words whose meaning they cannot find in the group were asked to the whole class. If it is still not solved, the teacher explains these words. Although it is not mentioned in the theoretical section, it would be more useful for teachers to write these words on the board.

Novak \& Gowin (1984) highlighted the most important concepts to create introductory and concept maps, such as "write the target words of the text on the board and request more samples from the students". Then, they present different concept teaching techniques such as "combining some pictorial concepts of teachers with these words and provide to keep these pictures in students' mind". It is observed that students note wrong words or wrote incorrectly the words of text during listening because of there is not enough Turkish language practice. The other reason of this is that students do not know some words which are used in Kurdish and Arabic language and they also have the same meaning in Turkish language. Students can sometimes use these words in a wrong way, sometimes wrong pronunciation and sometimes by mistaking them for a different word that they have different meaning and pronunciation, because they thought that the close pronunciation in their mother tongue has the same meaning in Turkish. Some of them are aware of this and solved this problem but some groups still did not notice this mistake.

The teacher should not say if the word is not included in the text and especially these words with correct pronunciation. The students should notice that by themselves and try to correct their own mistake during reading.

Thus, it has been seen that the method contributes to the other learning skills. Students will also analyze foreign language vocabulary. In the third and last stage of listening, the text is read again and this time different groups are created and they share information obtained within the group. The students actively carried out this process. Students improve their vocabulary by learning new words and their pronunciation in the reciprocally-grouped works (İzgören, 1999). It is observed that the students do not get bored in this work and this process passed in the game atmosphere.

When the text was played for the third time, it is asked to the students to analyze the subject within group. They listen to the text carefully and take notes. After listening, they discuss what they understand from the text. Then, each group tells what they understand from the text in the class. All of the groups talk the partly about a part of the text, not the whole text. Thus, the content began to be understood by trying to solve.

In the First sub-stage of Reading, the origin of text is shared with all students and it is asked to the students to read this text individually and silently. During the reading, they underline the words whose meaning they do not know. They read the text silently and they asked the words to friends and discuss within the group. When the words are not solved within the groups, they ask the whole class and teacher. All unknown words are written on the board.

In the third phase of the stage, "Common Dictionary "of students is created after this activity. Then, students read the text again, underline the words and exchanged information among the groups. So, new words are added to the students' dictionary. 
In the phase of "Lingua-Puzzle", the text is listened again by the students to improve their writing skills with the "Foreign Language Improvement Method". It is asked to the students to write what they hear from the listening. Students write what they hear carefully and compare each other's writing in dual groups, correct their mistakes and complete the deficiencies.

The point is in here that provides to teach the correct writing of words by listening, not only to determine the spelling mistakes (Chopan, 2008, p. 4).

If the content of the text is related with real life or enjoyable subject, it increases the interest of students. At the same time, it is indicator of how students are curious to try to understand text and solve it. In the last phase, students were asked questions about the text. The students answer the questions carefully and usually successfully.

In the same day, the other 3B grade students are compared with $3 \mathrm{~A}$ grade students who applied Anti-Method way. 3B grade students carried out the same text with the teacher-centered reading course and in accordance with the targeted purpose and course book's directives.

Two different evaluations were made on the measurement. First of them was about the test related both reading skills and listening skills. Besides understanding what they read, it was aimed to evaluate it to use in reading part. Thus, the values emerged between two classes.

Secondly, the questionnaire is applied about the pedagogical and psychological effects of method, the motivations, positive and negative effects of methods to the improvement of reading skills while learning second foreign language and using new, interesting and modern methods, and the experiences, observations and different evaluations of students were presented.

\subsection{Evaluation 1}

The measurement and evaluation of reading skills were prepared for the text and done with exam (See Appendix B). The exam questions are composed of 20 points for each section and a total of 100 points for "Collocations" "Prepositions used after verbs and adjectives", "Words that can be confused easily" and "Second meaning of a word" and "Fill in the missing words" (Listening and writing skills). The test was carried out in different classes and at the same time, under the same conditions as both control and experimental group.

The 3B grade students that selected Turkish course as a second foreign language gave out some results and evaluations of exam "Gençler İşsizlikten, Patronlar İşçisizlikten", they are as follows:

Table 2. Control group / 3B results

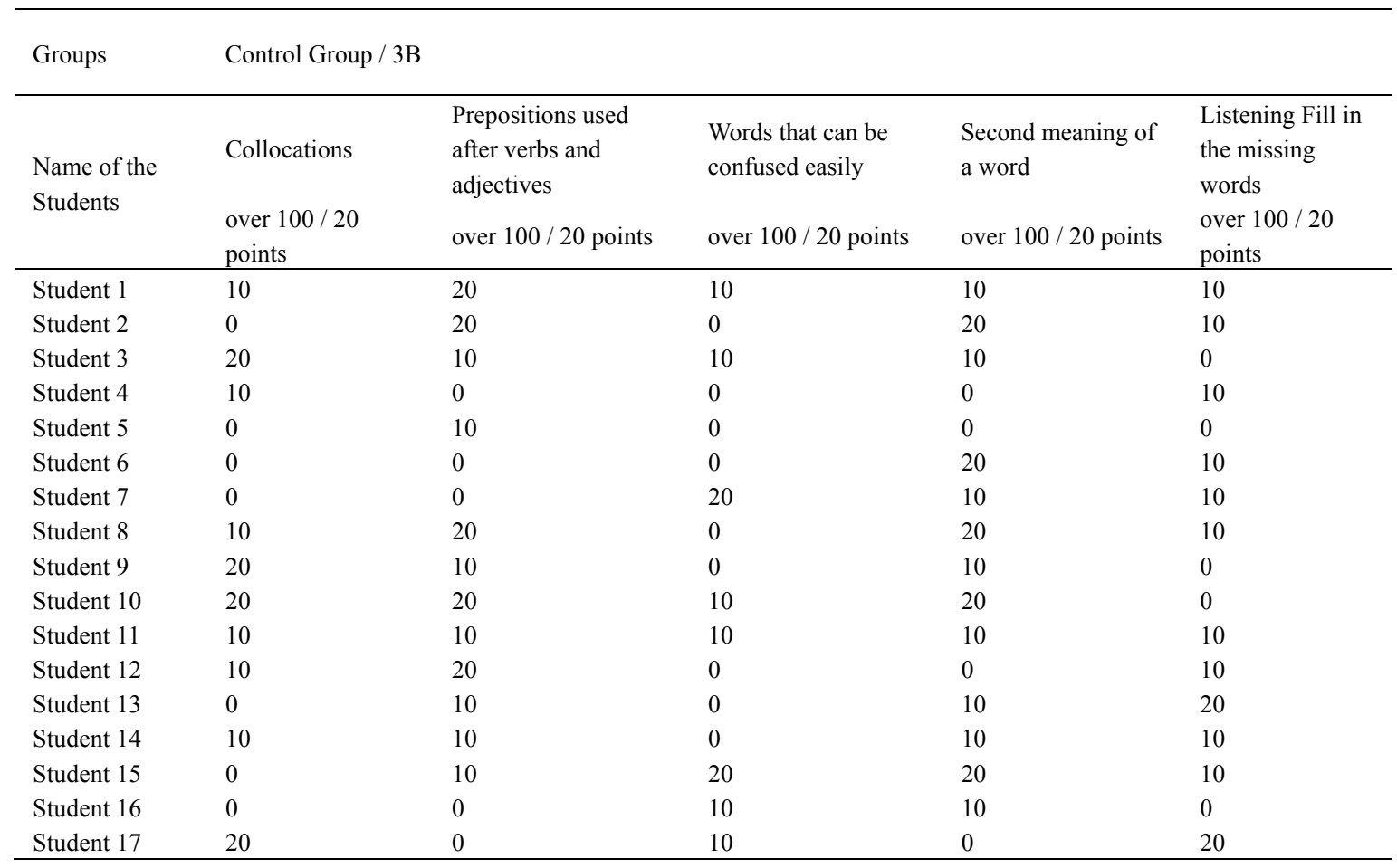




\begin{tabular}{llllll}
\hline Student 18 & 10 & 20 & 20 & 20 & 10 \\
Student 19 & 0 & 20 & 0 & 10 & 0 \\
Student 20 & 0 & 10 & 0 & 20 & 10 \\
Student 21 & 10 & 10 & 10 & 10 & 10 \\
Student 22 & 20 & 0 & 10 & 0 & 10 \\
Student 23 & 10 & 0 & 0 & 10 & 20 \\
Student 24 & 10 & 10 & 5.83 & 10.83 & 8.75 \\
Mean over 20 & 8.33 & 10.00 & & & $44 \%$ \\
points of Class & & & $54 \%$ & 43.75 \\
$\begin{array}{l}\text { Achieve } 20 \% \\
\text { Achievements }\end{array}$ & $42 \%$ & $50 \%$ & & & $43.75 \%$ \\
status & & & & \\
Total over 100 & & & & \\
points of Class & & & & & \\
Achieve $100 \%$ & & & & & \\
Achievements & & & & & \\
status & & & & & \\
\hline
\end{tabular}

As a result of the test, the student of control groups' achievement averages $42 \%$ ( 8.33 points) over $20 \%$ (over 20 points). "Prepositions used after verbs and adjectives" is 10 points over $50 \%$, "Words that can be confused easily" is ( 5.83 points) over $29 \%$ "Second Meaning of a word" is ( 10.83 points) over $54 \%$ and "Fill in the missing words" is ( 8.75 points) over $44 \%$. Overall success rate of the whole class is $43.75 \%$ (Over 100 / 43.75points).

The results of $3 \mathrm{~A}$ grade students who select the Turkish course as a second foreign language, aim to improve reading skills with Anti-Method way and study the target text which is "Gençler İşsizlikten, Patronlar İş̧isizlikten" are as follows:

Table 3. Experimental group / 3A results

\begin{tabular}{|c|c|c|c|c|c|}
\hline Groups & \multicolumn{5}{|c|}{ Experimental Group / 3A } \\
\hline \multirow{2}{*}{$\begin{array}{l}\text { Name of the } \\
\text { Students }\end{array}$} & Collocations & $\begin{array}{l}\text { Prepositions used } \\
\text { after verbs and } \\
\text { adjectives }\end{array}$ & $\begin{array}{l}\text { Words that can be } \\
\text { confused easily }\end{array}$ & $\begin{array}{l}\text { Second meaning of } \\
\text { a word }\end{array}$ & $\begin{array}{l}\text { Listening Fill in } \\
\text { the missing words }\end{array}$ \\
\hline & over $100 / 20$ points & over $100 / 20$ points & $\begin{array}{l}\text { over } 100 / 20 \\
\text { points }\end{array}$ & $\begin{array}{l}\text { over } 100 \text { / } 20 \\
\text { points }\end{array}$ & $\begin{array}{l}\text { over } 100 / 20 \\
\text { points }\end{array}$ \\
\hline Student 1 & 10 & 20 & 20 & 10 & 10 \\
\hline Student 2 & 0 & 20 & 10 & 20 & 20 \\
\hline Student 3 & 20 & 10 & 10 & 10 & 0 \\
\hline Student 4 & 10 & 10 & 20 & 20 & 20 \\
\hline Student 5 & 10 & 10 & 20 & 10 & 10 \\
\hline Student 6 & 0 & 20 & 10 & 20 & 10 \\
\hline Student 7 & 10 & 20 & 20 & 10 & 10 \\
\hline Student 8 & 20 & 20 & 0 & 20 & 10 \\
\hline Student 9 & 20 & 10 & 20 & 10 & 20 \\
\hline Student 10 & 10 & 20 & 10 & 20 & 10 \\
\hline Student 11 & 10 & 10 & 20 & 10 & 20 \\
\hline Student 12 & 20 & 20 & 10 & 20 & 20 \\
\hline Student 13 & 0 & 10 & 20 & 10 & 20 \\
\hline Student 14 & 20 & 10 & 10 & 20 & 0 \\
\hline Student 15 & 0 & 10 & 20 & 20 & 10 \\
\hline Student 16 & 20 & 0 & 10 & 10 & 20 \\
\hline Student 17 & 20 & 0 & 10 & 20 & 20 \\
\hline Student 18 & 10 & 20 & 20 & 20 & 10 \\
\hline Student 19 & 20 & 20 & 10 & 10 & 10 \\
\hline Student 20 & 20 & 10 & 10 & 20 & 10 \\
\hline Student 21 & 10 & 10 & 20 & 10 & 20 \\
\hline Student 22 & 20 & 10 & 10 & 20 & 10 \\
\hline Student 23 & 10 & 20 & 20 & 10 & 20 \\
\hline Student 24 & 20 & 10 & 10 & 0 & 20 \\
\hline
\end{tabular}




\begin{tabular}{|c|c|c|c|c|c|}
\hline $\begin{array}{l}\text { Mean over } 20 \\
\text { points of Class }\end{array}$ & 12.92 & 13.33 & 14.17 & 14.58 & 13.75 \\
\hline Achieve $20 \%$ & & & & & \\
\hline $\begin{array}{l}\text { Achievements } \\
\text { status }\end{array}$ & $65 \%$ & $67 \%$ & $71 \%$ & $73 \%$ & $69 \%$ \\
\hline $\begin{array}{l}\text { Total over } 100 \\
\text { points of Class }\end{array}$ & & & & & 68.75 \\
\hline Achieve $100 \%$ & & & & & \\
\hline $\begin{array}{l}\text { Achievements } \\
\text { status }\end{array}$ & & & & & $68.75 \%$ \\
\hline
\end{tabular}

The results of experimental group students whose applied Anti-Method way are that "Collocations" part's 20\% (over 20 points) success rate is $65 \%$ (12.95 points), "Prepositions used after verbs and adjectives" parts' rate is $67 \%$ (13,33 points), "Words that can be confused easily" parts' is $71 \%$ (14.17 points), "Second meaning of a word" parts' rate is $73 \%$ (14.58 points) and "Fill in the missing words" (Listening and writing) parts' rate is 69\% (13.75points). The overall success rate for whole class is $68.75 \%$ (over $100 / 68.75$ points).

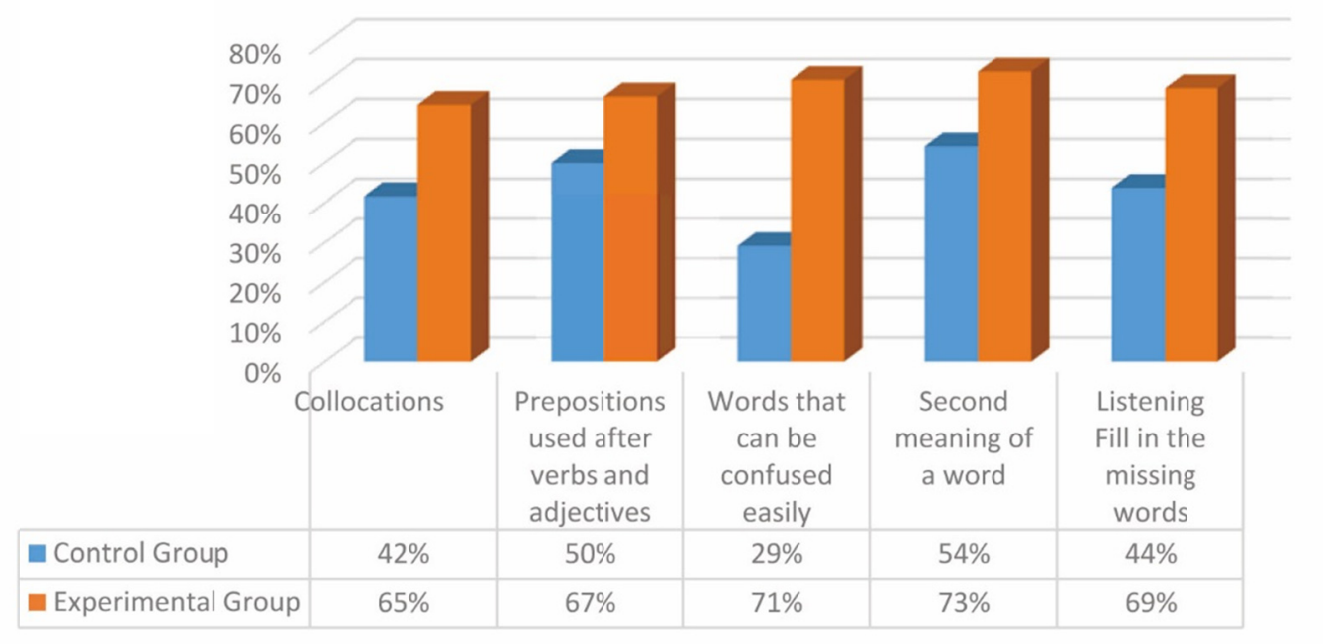

Figure 1. The results over 20 for five different types of questions

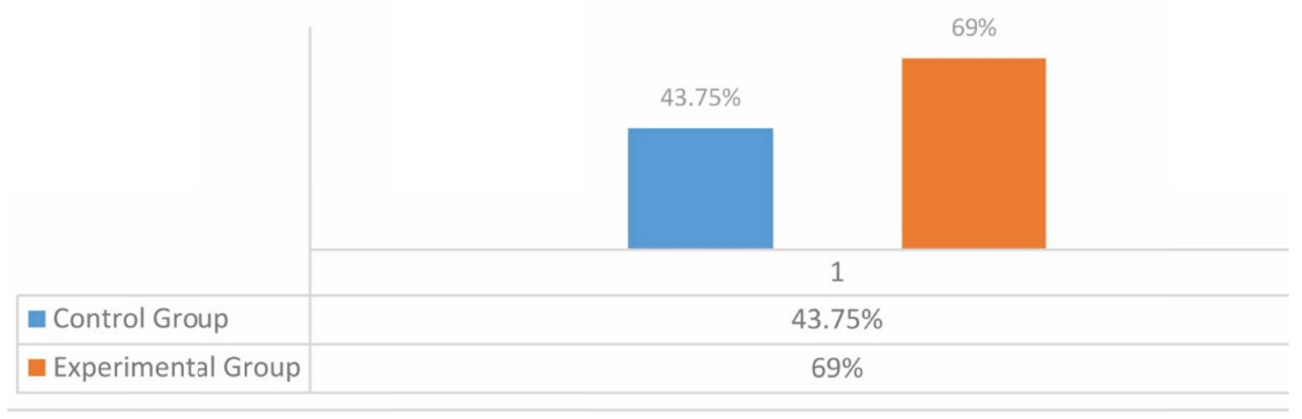

Figure 2. Total result over 100 points of groups

The table above and graphical values show the difference between students who applied "Anti-Method" way and who studied with the traditional reading skills. As a result of evaluations, there is $25.25 \%$ difference found between these groups.

\subsection{Evaluation 2}

This evaluation includes the feedbacks and comments of 3B grade students after applying "Anti-Method" way on experiment groups. At the end of this application, it is asked to write their own comments about Anti-Method 
by students (See Appendix C).

An educator and his seven students' opinion about the Anti-Method way are given in this section and these comments are evaluated.

\section{1) Educator}

Besides learning a foreign language, learning other foreign language requires patience and hardworking. Reading skills play an important role in terms of vocabulary and grammar, it directly addresses to listening and writing skills as well as improving reading skills. Before applying "Anti-Method", I think that all explanations about the method should be explained to the students in detail. Modifying the course plan and practice in accordance with the flexible, physical and cultural conditions increases the simplicity and applicability of this method. I have experienced that this method is more beneficial than the other teacher-centered education methods. In addition, the results of experiments which applied on the experiment and control groups show its truth.

\section{2) Student 1}

This activity we did in our class today is really beautiful. We proceeded step by step. The most important thing is that it is not teacher-centered. The teacher seemed like a helper. I felt like I and my friends discover it. I never felt a fear like "I said wrong, I made a mistake". When applying this method, the teacher should correctly explain this method and organize the class well. It was nice that teacher direct us by asking questions.

\section{3) Student 2}

The reading activates are perceived as boring in our class because Turkish course is perceived as boring. Since learning second foreign language brings new grammar rules and responsibilities, students do not want to read the texts and do not show interest in class activities. But this technique is both joyful and curious. I read the text curiously. Thanks to the technique, reading text is more enjoyable for me now. The intervention of teacher was very limited. We learned and understood the text by ourselves. I think our teacher also liked this method. Turkish was really hard for me, but with this method, it becomes easy and more enjoyable. I believe that with more reading skills activities, my Turkish would be more improved. I understood that with this technique it was a good experience for my future teaching career.

\section{4) Student 3}

The biggest problem for me in Turkish language is new words and I cannot guess the meaning of these new words in the text. This method shows me that I can understand the text easily. In addition, I believe that my participation to the activities in the class is maximized. Reading is also contributing to my recognition and writing activities.

\section{5) Student 4}

I think, one of the most factors that make a foreign language more interesting and attractive is related to using different materials and methods. It is so attractive that firstly we listen to the text at the beginning of lesson and then discuss our notes within group. It is not educator-centered; s/he has just a directive role. In short, it was more fun to learn with this way rather than traditional and teacher-centered methods. It became a pleasure to be out of classical methods and learning Turkish language.

\section{6) Student 5}

Turkish language has many words that came from Arabic language. Some of them have different meaning and pronunciation. For this reason, sometimes many words and their pronunciation mix each other. Generally, I have problems with reading and listening. Today, when I first time listened to the text, I thought I did not understand anything. But the activities provided to overcome my fear. Activities were made really enjoyably and easily. Doing pair-work and group-work are really important for in-class communication. I believe that it is very useful for us to use our mother tongue in some activities. I think the educator teach the words more permanently and attractive way. The content of the text is also important. We thank our teacher very much. We also use this method in our professional life.

\section{7) Student 6}

I am a daughter of Turkmen family in Iraq. Although Turkmen is a part of Modern Turkish language family, I find Turkish language difficult to understand. The main reason of this is that we do not use many grammar rules of Turkish in Turkmen. When I read the Turkish text, although I understand the general meaning, I misunderstood some part of the text because of using grammar which was not used in Turkmen. Even, sometimes reading activities become a torture for me. However, after this method, I saw that I can learn Turkish 
step by step and quickly. So, I found an alternative for my friends who have the same problem with me.

\section{8) Student 7}

I saw that "Anti-Method" way can be easily applied within class. I think this method includes also listening and writing skills, not only reading skills. The group work is the most enjoyable side of this method. By the way, I think our teacher is more positive and beneficial with this application.

When we evaluate these data as a result of this survey, we see that "Anti-Method" reached its target. It is also easily understood that students stated the lessons are more effective and they like this method. Students stated that they understood more easily with this method, which they stated that previously they could not understand under the normal conditions.

It was seen that students have effective learning process and get pleasure from the lessons with this method. Even if they are prejudiced to the new method, then they see that the new method is not difficult for them to adopt. Having fun of the lesson and communicating with other students are reported to prevent negative ideas against the second foreign language course.

The use of correct method in foreign language provides to remove prejudices of the students and leads them to the positive thinking. Furthermore, a student-centered method increases the communication among students and also provides that lessons are more effective. In addition, students who already know and speak Turkish but have pronunciation problems solved their problems with this "Anti-Method" way. Students have the opportunity to develop and operate four basic skills at the same time. So, it ensures that learning language is provided with the best learning method.

As it is understood from the comments, the use of traditional methods in foreign language education causes the students to get bored. Now, students want enjoyable courses. Alternative methods are the most important tools that can realize this. However, the teacher can also use traditional methods but they should be used in the right time and right place. For this reason, teachers should use all kinds of methods at appropriate places when necessary.

\section{Conclusion}

In this study, "Anti-Method" way is promoted which is an alternative way to solve problems encountered by students when they learn a new foreign language. It provides more effective and easier way of learning foreign language. As a result of two different assessments made on the students, "Anti-Method" provides positive results when it is applied properly in the classroom. In addition, the flexible structure of Anti-Method to the environmental and cultural values provides an extra advantage for both students and teachers.

The objective feedbacks from students show that foreign language courses do not consist only of grammar, even some things can be thought without linguistic knowledge. Independent of this method, group works within the classroom and mutual activities increase the language skills of students and applicability of this method. The first target of language education is to have the students like new language, teaching new methods which are student-centered, encouraging students to explore and learn target language and doing this not only at universities but also all levels of classes.

\section{References}

Al-Hamash., \& Younis, H. (1985). Principles Techniques of Teaching English as a second Language (6th ed.) Baghdad: IDELTI.

Anderson, H. A. (1960). Teaching the Art of Listening, Perspectives on English (In R. C. Pooley Ed.). New York: Appleton-Century-Crofts, Inc.

Atkinson, A. (1987). The mother tongue in the classroom: a neglected resource? ELT Journal, 41(4), 241-247. https://doi.org/10.1093/elt/41.4.241

Bolitho, R. (1983). Quoted in talking shop. ELT Journal, 37(3), 235-242.

Brown, H. D. (2007). Teaching by Principles: An Interactive Approach to Language Pedagogy. New York: Pearson Education.

Buttaroni, S. (1997). Fremdsprachenwachstum Sprachenpsychologischer Hintergrund und Didaktische Anleitungen, Hueber Verlag, Ismaning.

Buttaroni, S., \& Knapp, A. (1988). Fremdsprachenwachstum. Anleitungen und sprachpsychologischer Hintergrund für Unterrichtende, Fernkurse der Wiener Volkshochschulen, Wien. 
Çeçen, M. A., \& Çiftçi, Ö. (2007). Nlkögretim 6. Sınıf Türkçe Ders Kitaplarında Yer Alan Metinlerin Tür ve Tema Açısından Nncelenmesi. Milli Egitim Dergisi, 173, 39-49.

Chopan, S. M. (2008). Diktate- Probleme und Herausforderungen im Rechtschreibunterricht. Retrieved from http://www.grin.com/e-book/116968/diktate-probleme-und-herausforderungen-im-rechtschreibunterricht

Demirel, Ö. (1978). Tam Öğrenme. Ĕgitim ve Bilim Dergisi, 46-50.

Diaz-Rico, L. (2013). Strategies for Teaching English Learners. Trenton, NJ: Pearson.

DiVesta, F., \& Grey, G. S. (1972). Listening and note-taking. Journal of Educational Psychology, 63, 8-14. http://dx.doi.org/10.1037/h0032243.

Dror, I. E. (2007). Land mines and gold mines in cognitive technologies. In I. E. Dror (Ed.), Cognitive technologies and the pragmatics of cognition (pp. 1-7). Amsterdam: John Benjamin Press. https://doi.org/10.1075/bct.12.02dro

Dror, I. E., \& Harnad, S. (2008). Offloading cognition onto cognitive technology. In I. E. Dror \& S. Harnad (Eds), Distributed Cognition: How Cognitive Technology Extends Our Minds (pp. 1-23). Amsterdam: John Benjamins. https://doi.org/10.1075/bct.16.02dro

Duman, A. (2003). Türk Soylulara Türkiye Türkçesi Ögretiminde Metin Seçimi. Türklük Bilimi Arastırmaları (Türkçenin Ögretimi Özel Saylsl), 13, 151-154.

Durkin, D. (1979). What Classroom Observations Reveal about Reading Comprehension. Reading Research Quarterly, 14(4), 481-533. https://doi.org/10.1598/RRQ.14.4.2

Durkin, D. (1984). Is There a Match between What Elementary Teachers Do and What Basal Reader Manuals Recommend? Retrieved from https://www.ideals.illinois.edu/bitstream/.../ctrstreadeducrepv01983i00044_opt.pdf

Ehlers, S. (1996). Lesen als Versehen. Fernstudien 2, Langenscheidt, Berlin.

Finocchiaro, M., \& Brumfit, C. (1983). The Functional-Notional Approach. Oxford: Oxford University Press.

Fodor, J. A. (1975). The Language of Thought. New York: T. Y. Crowell.

Gümüş, S. (2010). Çiftli Sarmal Bulmaca. Retrieved January 1, 2011 from http: //bullmacaservisi.com.

Gürgen, İ. (2008). Türkçe Öğretimi. Eskişehir: Anadolu Üniversitesi Yayınları.

Hinkel, E. (2006). Current perspectives on teaching the four skills. TESOL Quarterly, 40(1), 109-131. http://dx.doi.org/10.2307/40264512

Holden, J. (2004). Creative Reading. London: Demos.

İzgören, K. M. (1999). Oyunlarla Dil Öğretimi. Ankara: Academyplus Yayınları.

Karatay, H. (2007). Kelime Öğretimi. Gazi Ĕ̆itim Fakültesi Dergisi, 27(1), 121.

Keçik, İ., \& Uzun, L. (2004). Türkçe Sözlü ve Yazllı Anlatım. Eskişehir: Anadolu Üniversitesi Açık Öğretim Fakültesi Yayınları.

Küçük, S. (1996). Türkçe Ögretiminde Metin Seçimi ve Önemi. Dil Dergisi, 43, 10-14.

Lewandowski, T. (1994). Linguistisches Wörterbuch 3, Quelle \& Meyer, Heidelberg.

Novak, J. D., \& Gowin, B. (1984). Learning How to Learn. New York: Cambridge University Press. https://doi.org/10.1017/CBO9781139173469

\section{Appendix A.}

Tarih / Date:

\section{Değerli katılıme, (Dear participant)}

Lütfen, aşağıdaki sorulara göre Türkçe Dili hakkındaki görüşlerinizi yazınız.

(Please, write your opinions about the Turkish language according to the following questions.)

1) Yabancı dil öğrenmeyi seviyormusunuz? Neden? / Do you like learning foreign language? Why?

2) Yabancı bir dil öğrenmek ihtiyaç mıdır? Neden? / Do you think learning foreign language is a need? Why? 
3) Türkçe dilini seviyor musunuz? / Do you like Turkish language?

4) Türkiye'de daha önceden hiç bulundunuz mu? Have you ever been in Turkey before?

5) Lise eğitimiz döneminde Türkçe dersi aldınız mı? / Did you take a Turkish lesson in high school?

6) 2. Yabancı dil olarak Türkçe'yi hangi seviyede öğrendiğinizi düşünüyorsunuz? / What do you think about how much level you learned Turkish as a second foreign language?

7) 2. Bir yabancı dil olarak Türkçe dilini neden öğrenmek istiyorsunuz? Neden? / Why do you want to learn Turkish language as a second foreign language? Why?

8) Türkçe dilini ailenizde konuşan var mı? / Does anyone speak Turkish language in your family?

9) Size göre Türkçe zor bir dilmidir? Neden? / Is Turkish a difficult language for you? Why?

10) Yabanci bir dil dersi nasıl olmalıdır? / How should be a foreign language lesson?

Değerlendirme anketine katıldığınız için teşekkür ederiz. / Thank you for participating evaluation survey.

Appendix B.

Examination / İmtihan

İsim: Name:

Tarih / Date:

Soyisim: Surname:

Aşağıdaki soruları cevaplayınız: Answer the following questions.

1) alan

$\begin{array}{llll}\text { a-) yaratmak } & \text { b-) yatırmak } & \text { c-) yalatmak } & \text { d-) yaktırmak }\end{array}$

2) Aşağıdakilerden hangisi doğrudur? / Which one is true?
a-) iş satmak
b-) iş bulmak
c-) iş sevmek
d-) iş gitmek

3) Aşağıdakilerden hangisi doğrudur? / Which one is true?
a-) iş bul şansı
b-) iş bulmak şansı
c-) iş bulmuş şansı
d-) iş bulma şansı

4) Ne yazık günümüzde işsizlik, en önemli sorunlardan birisidir.

a-) ve

b-) de

c-) ile

d-) ki

5) Aşağıda yazan bu iki cümleyi incelediğinizde sizce bir fark varmıdır?

Is there any difference between these two sentences?

"Yeni istihtam alanları oluşturmak."

"Yeni istihtam alanlarl yaratmak."
a-) Evet
b-) Hayır
c-) Emin değilim.

6) düzgün
a-) temiz
b-) güzel
c-) tertipli
d-) bakımlı

7) "eleman" nedir? / What is "an emplovee"?
a-) bitki
b-) makine
c-) insan
d-) iş

8) Aşağıdaki resimlerden hangisi "gençler" kelimesinin karşılığıdır? Which picture means "young"? 
a-)

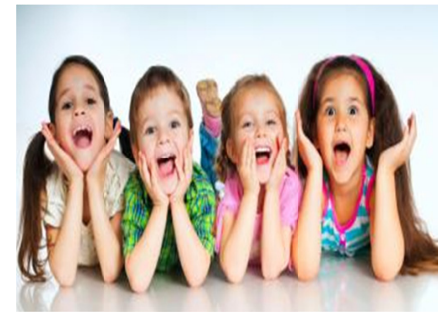

c-)

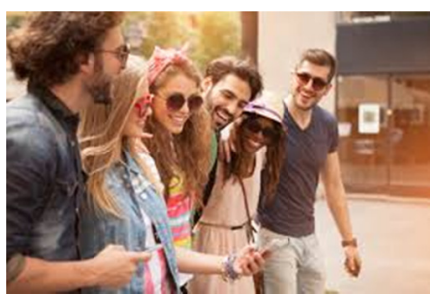

b-)

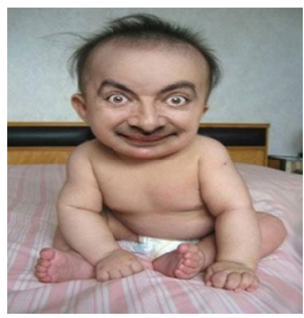

d-)

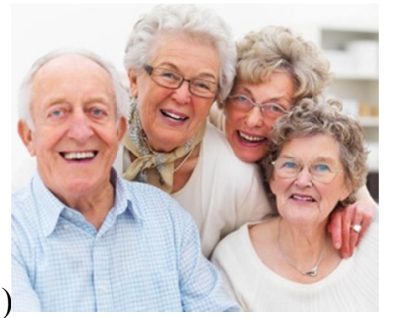

9) Eğer cümle yanlış ise lütfen düzeltiniz. Correct these sentences if they are not true.

a-) ....firma eleman alırken kafasını kırk yarıyor.

b-) Buda ancak doğru politikalarla mümkün olabilir.

c-) Oysaki günümüz koşularında ekmek aslanın kafasında.

d-) En az bir veya iki yerli dil bilmek.

\section{0) Sınavınızı bitirdiğinizde aşağıdaki kelimeleri lütfen öğreticinize telaffuz ediniz.}

When you finish your exam, please pronounce the following words to your teacher.

$\begin{array}{ll}\text { Kalifiye } & \text { Günümüzde } \\ \text { Mide } & \text { Sadece } \\ \text { Çözmek } & \text { Artık } \\ \text { Vasıfsız } & \text { Tabi ki } \\ \text { Çağlarında } & \text { İşsizlik } \\ \text { Yetiştirmeli } & \text { İşletmeler }\end{array}$

\section{Appendix C.}

Anti-Method

Tarih / Date:

Dear Participants,

Today, you have experienced with the different way of "Anti-Method" to develop second foreign language Turkish within the class. We asking to share with us positive and negative opinions about the aspects of this method. Thank you for participating in this evaluation questionnaire.

İsteğe bağlı olarak, İsim ve soy isminiz:

(Depending on your request, Name and Surname) 


\section{Appendix D.}

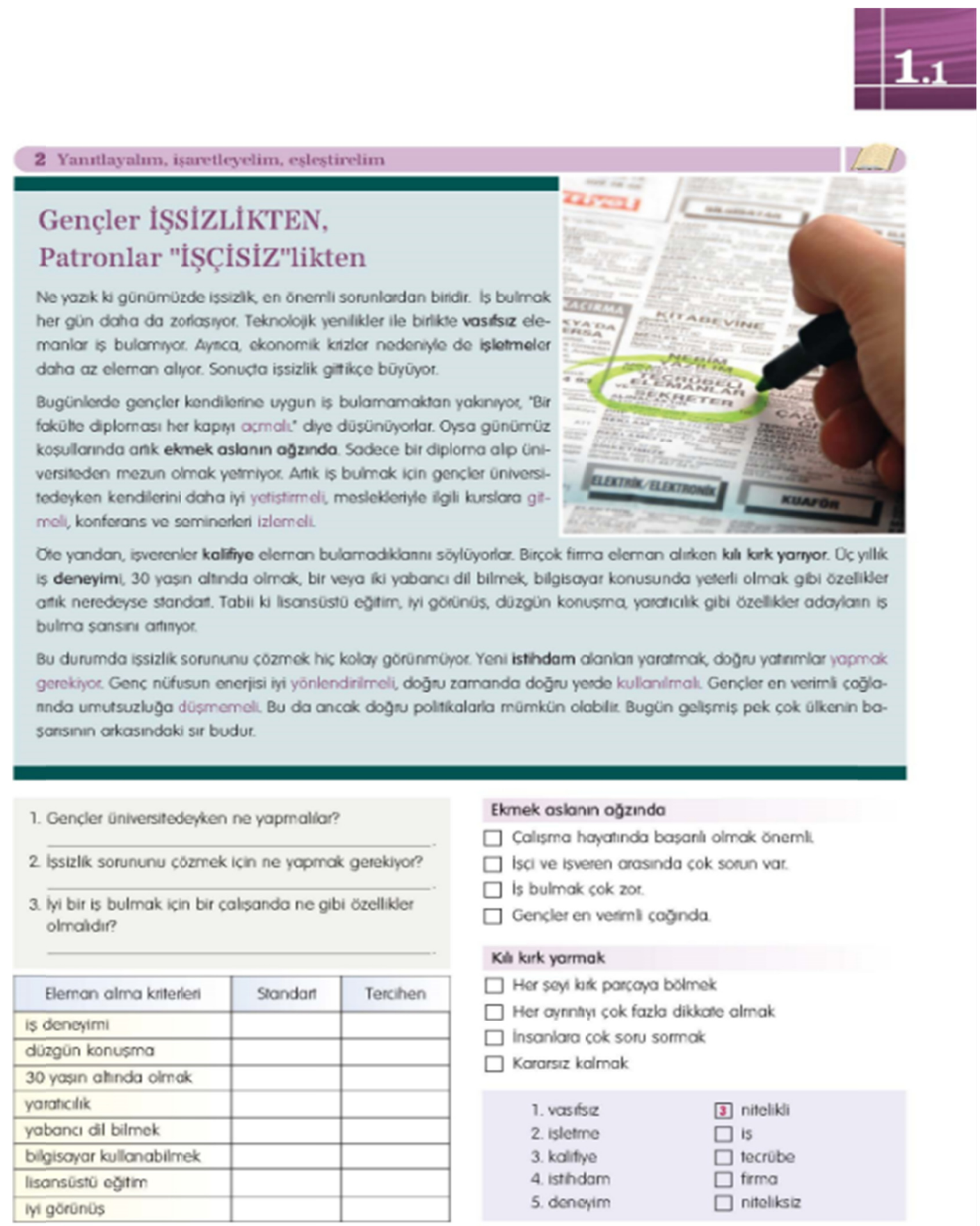

\section{Copyrights}

Copyright for this article is retained by the author(s), with first publication rights granted to the journal.

This is an open-access article distributed under the terms and conditions of the Creative Commons Attribution license (http://creativecommons.org/licenses/by/4.0/). 